\title{
REVIEW OF COMPOSITE MATERIALS APPLICATIONS IN MARINE INDUSTRY
}

\author{
Adrian Caramatescu \\ University "Dunarea de Jos" of Galati, \\ Faculty of Naval Architecture, Galati, Domneasca \\ Street, No. 47, 800008, Romania, \\ E-mail:adrian.caramatescu@ugal.ro
}

\author{
Costel Iulian Mocanu \\ University "Dunarea de Jos" of Galati, \\ Faculty of Naval Architecture, Galati, Domneasca \\ Street, No. 47, 800008, Romania, \\ E-mail:costel.mocanu@ugal.ro
}

\begin{abstract}
As in many industrial domains, applications of composite materials show a constant growth in the marine industry. The possibility to create a specific combination of materials and engineering proves that they work together better than any of them independently, thus generating a wide range of applications that challenge the naval architects of today. The paper presents a brief review of the development of this class of materials and their advantages for the shipbuilding and boatbuilding industry.
\end{abstract}

Keywords: composite materials, planing hull, sandwich structures, FEA.

\section{INTRODUCTION}

In the technical literature there are many definitions for composite materials, but all converge to a common concept: composite materials are materials obtained by combining, on a macroscopic scale, two or more different materials to form a new material where the deficiencies of a component are offset by the benefits of the other component. The constituents retain their identities in the composite by not dissolving or mixing completely with one another while acting together. Typically, components can be physically identified and have a visible macroscopic interface that separates them one from the other [1].

According to the above, the term "composite material" defines a vast class of products made up of materials of different nature. The designing engineer can combine two or more different materials in order to obtain a new material that exhibits certain improved features. These combinations are virtually infinite.The main advantage of composite materials is that, if they are properly de- signed and put into work, they usually present the best qualities of the constituents and, most of the times, qualities that none of the constituents present independently.

Different materials can also be combined on a microscopic scale, such as in metallic alloys, but the resulting material is macroscopically homogeneous, the components are not distinguishable with the naked eye, these materials are not to be considered composite materials. In order to separate the composite materials from the rest of the materials obtained by combining two or more materials, it should be noted that in the finished composite material obtained after the combination, the constituent materials are distinct, physically differentiable and mechanically separable [2].

In most cases, in the composite material one can distinguish two components, called phases: one of the materials is the matrix and is defined as the continuous phase. The reinforcement is the second constituent element of the composite material and is also referred to as reinforcement. It completes the matrix to improve its properties. The reinforcement 
is the discontinuous phase, evenly distributed throughout the matrix volume [3]. The roles of each of the constituent elements are highlighted in Table 1 [1].

Table 1. Phases in a composite material [1]

\begin{tabular}{|c|c|}
\hline \begin{tabular}{l}
\multicolumn{1}{c}{ Matrix } \\
- Provides the shape of the \\
composite piece \\
- Supports reinforcement \\
material \\
- Protects reinforcement \\
against external factors \\
- Transfers effort to rein- \\
forcement \\
- Contributes to properties \\
that depend on both rein- \\
forcement and matrix, such \\
as mechanical strength, \\
brittleness, plasticity, stiff- \\
ness \\
- Redistributes tasks when \\
some reinforcement ele- \\
ments fail
\end{tabular} & $\begin{array}{l}\text { Reinforcement } \\
\text { - Provides material } \\
\text { strength and stiffness } \\
\text { - Has a dominant role in } \\
\text { other properties such as } \\
\text { thermal expansion coeffi- } \\
\text { cient and heat transfer } \\
\text { - Improves matrix quali- } \\
\text { ties such as rigidity or } \\
\text { elasticity, tensile strength, } \\
\text { compression, bending, } \\
\text { wear, fatigue, various } \\
\text { other physical or chemical } \\
\text { properties } \\
\text { - Bears most of the ex- } \\
\text { ternal effort, therefore the } \\
\text { shape and orientation of } \\
\text { the reinforcement in the } \\
\text { composite must be care- } \\
\text { fully chosen in such a } \\
\text { way that it is optimal to } \\
\text { the stresses to which the } \\
\text { composite is to be sub- } \\
\text { jected }\end{array}$ \\
\hline
\end{tabular}

It should also be noted that, in addition to the advantages, composite materials also have a number of drawbacks. Some of these are described in Table 2; the considerations are of a general nature, given that the composite materials can be made up of several combinations of materials, as will be described in this chapter. For each application, the advantages and drawbacks should be weighed carefully so that the material chosen will provide the best properties tracked in that application.

\section{APPLICATIONS OF COMPOSITE MATERIALS IN THE SHIPBUILDING INDUSTRY}

The origins of composites used as shipbuilding material date back to the Second World War. The US Navy then launched a 8,.5-meter-long river patrol boats, relying on the material's potential to reduce maintenance and production costs.
In 1960 Owens Corning, a fiberglass manufacturer, funded the design office "Gibbs \& Cox" to draft "Marine Design Manual for Fiberglass Reinforced Plastics". This book, published by McGraw-Hill Publishing House, was the first composite material design guideline to focus on the watercraft industry.

Information that is publicly available includes only declassified items from research and development projects, often published more than 15 years after the construction. It is obvious that the defense industry has always been the spearhead of research in most areas, so the materials, in general, and the composite materials, in particular, are no exception.

Table 2. Composites advantages and drawbacks [4], [5]

\begin{tabular}{|c|c|}
\hline $\begin{array}{l}\text { Advantages } \\
\text { • Low weight } \\
\text { - High specific rigidity } \\
\text { - High specific resis- } \\
\text { tance } \\
\text { - Anisotropy - different } \\
\text { characteristics depending } \\
\text { on the orientation direction } \\
\text { - Excellent formability in } \\
\text { complex geometries } \\
\text { - Accumulate multiple } \\
\text { components in one ele- } \\
\text { ment, thus reducing the } \\
\text { cost of the assembly } \\
\text { - Easily bonded by } \\
\text { bonding } \\
\text { - Good damping } \\
\text { - Good shock resistance } \\
\text { - Capacity to store and } \\
\text { release internal energy } \\
\text { - Low expansion coeffi- } \\
\text { cient } \\
\text { - Low electrical conduc- } \\
\text { tivity } \\
\text { - Invisible for radar sys- } \\
\text { tems (STEALTH) } \\
\text { - Thermal and electrical } \\
\text { conductivity (carbon fiber } \\
\text { only) }\end{array}$ & $\begin{array}{l}\text { - The cost of raw ma- } \\
\text { terials } \\
\text { - Lack of universally } \\
\text { valid design rules } \\
\text { - Using the same pro- } \\
\text { ject for metal and com- } \\
\text { posite is rarely possible } \\
\text { - Long development } \\
\text { times } \\
\text { - Difficulties of putting } \\
\text { into work (manual, slow, } \\
\text { environmental problems, } \\
\text { low repeatability) } \\
\text { - Specific assembly } \\
\text { organs } \\
\text { - Low ductility (joints } \\
\text { are often ineffective and } \\
\text { concentrate higher } \\
\text { stress than metals } \\
\text { - Susceptible to attack } \\
\text { by solvents } \\
\text { - Thermal operating } \\
\text { limits } \\
\text { - Susceptible to de- } \\
\text { fects } \\
\text { - Hidden defects } \\
\text { - Electromagnetic } \\
\text { shielding is sometimes } \\
\text { required }\end{array}$ \\
\hline
\end{tabular}

In the naval field, composite materials are used on the body, decks, bulkheads, masts, propulsion shafts, rudders, and other elements installed on mines, frigates, destroyers, corvettes and aircraft carriers. Ex- 
tensive use of composite materials can be seen in the Swedish Royal Navy's Visby class, measuring 72 meters in length and 10,4 meters in width (Figure 1). This ship is the largest military ship built using composite materials (carbon fiber in the sandwich structure with vinyl esther resin matrix). If Visby was to be made of traditional metallic materials, the total mass would have been almost double (1,200 tons), making composite material largely responsible for the performance of the corvette.

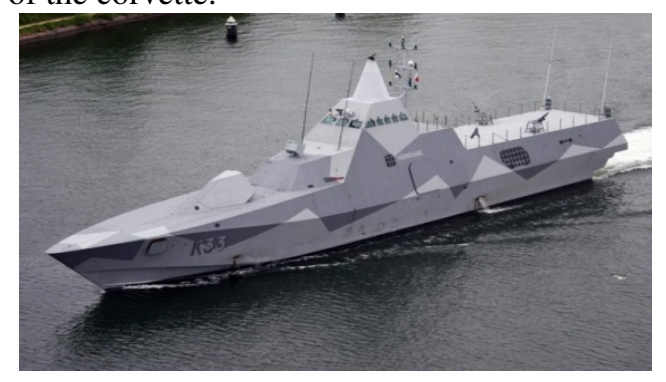

Fig.1. Visby Class Swedish Corvette

With regard to submarine constructions, the applications are multiple, ranging from the periscope fairings to the domes of rocket launching capsules on the battle submersibles. We can also mention unmanned devices whose structure and buoyancy elements are made of composite materials: the thick walls of high pressure resistant cells are made of fibrous composite materials and the buoyancy elements are made of syntactic foam. The Naval Architecture Faculty of Galaţi participated in the reserach grant TOYROV 12$116 / 2008$ during which there were developed and studied 25 constructive solutions for an autonomous submarine vehicle (Figure 2)

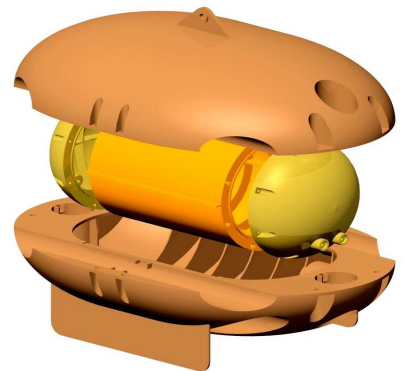

Fig.2. TOYROV rendering [6]
Navigation buoys in composite materials are lightweight and thus reduce damage to ship collisions. They are usually made of polymer matrix composites such as polyethylene foams, polyurethane elastomers, and glass fiber reinforced plastics.

In large ships, composite materials are used in the construction of superstructures or various modular components. For example, the "Queen Mary 2" transatlantic cruise ship used composite materials to build over 800 partition walls and doors. Much of the design documentation of this ship was carried out at ICEPRONAV Galati [4].

\section{APPLICATIONS OF COMPOSITE MATERIALS IN THE BOATBUILDING INDUSTRY}

Fiberglass reinforced polyesters have been used in various types of craft (yachts, small boats, fishing boats, small service boats, lifeboats) since the introduction of the material into the commercial circuit in the 1940s. At present, almost $90 \%$ of all recreational boats are built either from fiberglass reinforced polyester resin or fiberglass reinforced viniless resins, used for hull, deck, various structural applications, or interior subdivisions. The manufacturing process used in the vast majority of applications is hand lay-up in open molds, which, although it is a laborious process involving a lot of work in difficult working conditions, has a major advantage in that the molds used in production are cheap and thus more accessible to many manufacturers of such craft.

The use of composite materials in the marine industry in Romania is still quite underdeveloped. One of the largest composite ships recently built in our country is a general cargo boat of $17 \mathrm{~m}$ in length having a load capacity of 30 tons, built and designed by PLASMA Galati, shown in Figure 3.

The largest pleasure craft built from composite materials is the $75 \mathrm{~m}$-long yacht Mirabella, launched in 2003. Although boats of this size are usually made of aluminum or 
steel, in the case of Mirabella V (Figure 4) the material of choice was composite due to the speed of construction, the low maintenance of the hull surface and the good acoustic and thermal insulation offered.

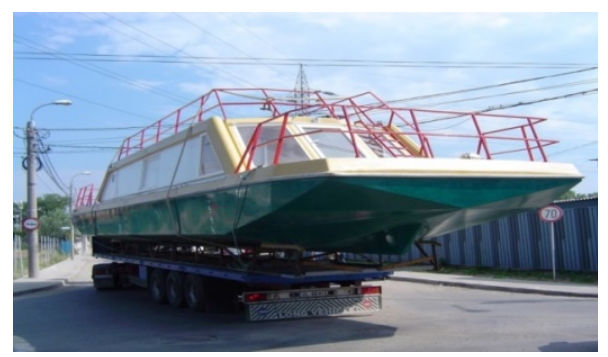

Fig.3. Cargo boat built in Galati

Although in each watercraft workshop there are employed different techniques with different particularities, the overall directions of the industry can be quantified and centralized based on data reports from the manufacturers and distributors of raw materials used in the composite industry. Each time an improvement has been made to the manufacturing techniques, the raw material manufacturers have adapted their offer to the users' requirements, as can be seen in the graph presented in Figure 5 [7].

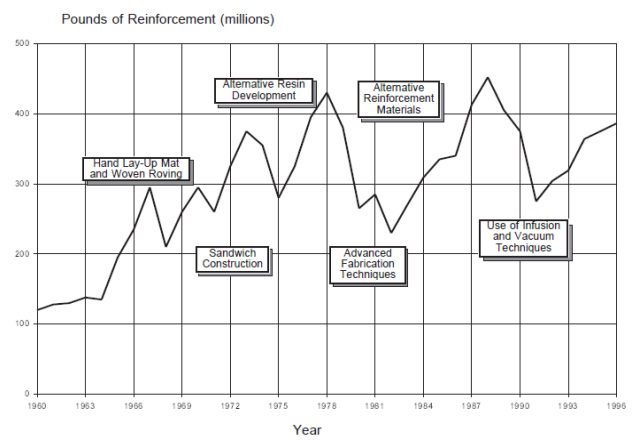

Fig.4. Reinforcement deliveries 1960-1996

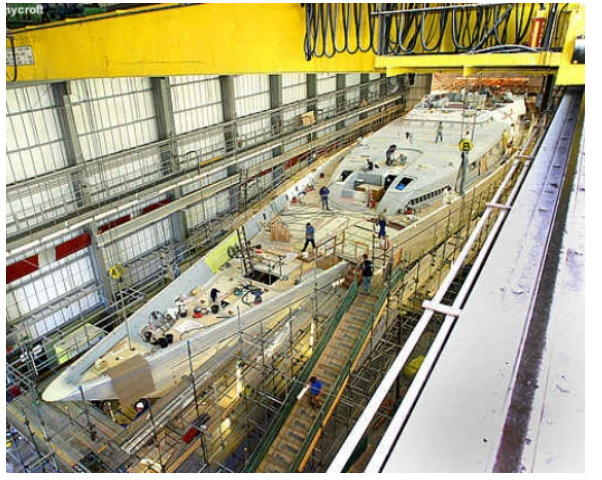

Fig.5. Mirabella V

\section{FUTURE DEVELOPMENT OF COMPOSITES IN MARINE INDUSTRY APPLICATIONS}

One of the advantages of composite materials is that certain features specifically sought by the designer can be modified by relatively easy-to-operate changes in the way the final laminate is obtained.

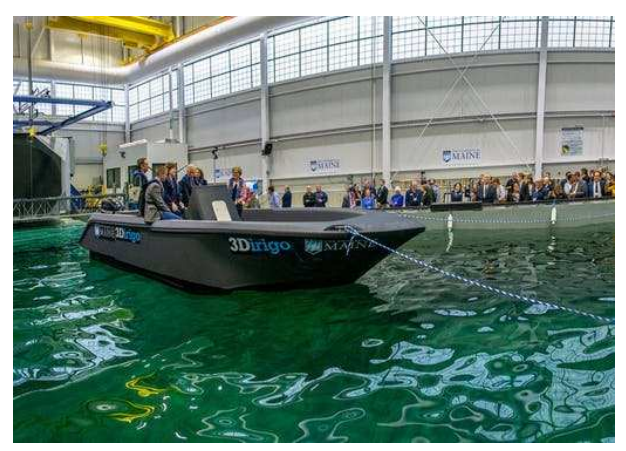

Fig.6. 3d printed composite boat [9]

Besides various changes in the recipes of the resins and multiple choices of the reinforcing materials, spatial structures obtained with multiple core materials in sandwich laminates are a solution for lightweight composites. Due to the ease with which both the skins and the core material can be changed in the technological process of obtaining the laminate, this structure offers a great flexi- 
bility in designing alternative variants with different degrees of rigidity [8].

In October 2019 University of Maine Composites Center received three Guinness World Records for prototyping a full scale 7.62 m boat: for the world's largest prototype polymer 3D printer, largest solid 3D-printed object, and largest 3D-printed boat. (Fig 6, ),$[9]$.

The direction of the composites development in the marine business comes hand in hand with the CAD and CAM domains. Complex structural demands challenge engineers to search for contemporary competing materials and designs.

\section{CONCLUDING REMARKS}

Improvement of composite material structures considering sandwich systems is a good approach if the goal is to reduce the mass and increase the rigidity of the structure. The numerical approach of the design stages is an increasingly common solution due to the multiple software solutions and the variety of scientific papers presented at international conferences and scientific journals [9] - [25].

In all the described examples above the composite materials assumed the role played by the classical materials, especially metals or alloys of metals. This substitution was dictated by aspects related to the evolution towards a modern product, in which the operating life and safety increase, the need for periodic maintenance is reduced and the economy of resources during production and in operation is significantly increased. All these aspects are closely related to the mass of the assembly and the composite material is the key material that contributes to reducing the mass to an optimum point at a given time. As this optimum is mobile over time, it is a function of the technologies available at the moment and the modernization of the products obtained from composite materials, it is a continuous, evolutionary activity. Continuous specialization of designers working with composite materials is a key factor for prod- uct performance; the increasing variety of exhibitions, conferences and scientific communication sessions in this field offers a great possibility to know and exchange information with other researchers.

\section{REFERENCES}

[1]. U.S. Department of Defense Handbook: "Composite materials handbook, Volume 3: Polymer matrix composites - materials, design and analysis", MIL-HDBK 17-3F, Volume 3 of 5, US Department of Defense 2002.

[2]. Strong, A.B., "Fundamentals of composites manufacturing: materials, methods and applications", second edition, 2007;

[3]. Mallick, P. K., "Fiber-Reinforced Composites - Materials, Manufacturing and Design”, Taylor Fracis Groul LLC, 2007;

[4]. Beznea, E.F. , Chirică, I., "Structuri Compozite”, Galati University Press, 2010, ISBN 978-606-8008-86-8;

[5]. Andrei, G., Dima, D., Bîrsan, I.G., Andrei, L., Cîrciumaru, A., "Effect of Ferrite Particles on Mechanical Behaviour of Glass Fibers Reinforced Polymer Composite”, Revista de Materiale plastice, Vol 46, nr 3, p. 284 - 287, 2009;

[6]. Domnișoru, L., Dragomir, D., Mocanu, C.I., Domnișoru,D., "Proiectarea preliminară structurală a unui vehicul subacvatic din materiale compozite”, Galați University Press, 2010.

[7]. ***, "Composite Material Study: Maturity of Technology Materials and Fabrication, F.I.T." Structural Composites Laboratory technical report prepared for UNISYS Corporation and U.S. Navy, 1998;

[8]. Davalos, J. F., Qiao, P. Z., Xu, X. F., Robinson, J., and Barth, K. E., "Modeling and characterization of fiber-reinforced plastic honeycomb sandwich panels for highway bridge applications", Journal of Composite Construction, nr 52, p. 441-452, 2001, DOI: 10.1016/S0263-8223(01)00034-4 ISSN: 0263-8223;

[9]. https://archinect.com/news/article/15016590 4/the-university-of-maine-sets-three-worldrecords-by-3d-printing-a-25-foot-longboat\#\& gid $=1$ \&pid $=1$

[10]. Davies, J.M., "Design Criteria for Structural Sandwich Panel", Journal of Structural Engineering 65A (12), p. 435-441, 1987; 
[11]. Hassinen, P., "Compression Failure Modes of Thin Profiled Metal Sheet Faces of Sandwich Panels, Sandwich Construction”, Proceedings of the Third International Conference, Southampton, p. 205-214, 1995;

[12]. Davies, J.M., "Sandwich Panels. ThinWalled Structures", no 16, p.179-198, 1993;

[13]. Davies, J.M., "Light Weight Sandwich Construction", Blackwell Science, UK, 2001;

[14]. ***, "International Council for Building Research, Studies and Documentation (CIB) European Recommendations for Sandwich Panels Part 1: Design", CIB Publication 147, 2000;

[15]. Davies, J.M. and Hakmi, M.R., "Local Buckling of Profiled Sandwich Plates", Proc. IABSE Symposium, Mixed Structures including New Materials, Brussels, September, p. 533-538, 1993;

[16]. Davies, J.M. and Hakmi, M.R., "Postbuckling Behaviour of Foam-Filled Thin Walled Steel Beams", Journal of Construction Steel Research, 20, p. 75-83, 1992

[17]. Hibbitt, Karlsson and Sorensen, Inc., (HKS) . "Abaqus User's Manual, Pawtucket”, RI, USA, 1998;

[18]. ***, "Abaqus user manual, http://abaqus.software.polimi.it/v6.14/index. html", 2014;

[19]. Davies, J.M., Hakmi, M.R. and Hassinen, P., "Face Buckling Stress in Sandwich Panels", Proc. Nordic Steel Colloquium, p. 99110, 1991;
[20]. $* * *$

https://docs.plm.automation.siemens.com/dat a_services/resources/nxnastran/11/

help/tdoc/en_US/pdf/User.pdf;

[21]. Davies, J.M. and Heselius, L., "Design Recommendations for Sandwich Panels", Journal of Building Research and Information, 21(3), p. 157-161, 1993;

[22]. Pokharel, N. and Mahendran, M., "Local Buckling Behaviour of Sandwich Panels", Proceedings of the Third International Conference on Thin-Walled Structures, Krakow, Poland, p. 523 - 530. 2001;

[23]. Domnișoru, L., "Metoda elementului finit în construcții navale”, Editura Tehnică, București, 2001, ISBN: 9733120235 ;

[24]. Hadăr, A., "Probleme locale la materiale compozite", Universitatea "POLITEHNICA" Bucureşti, 1997;

[25]. Caramatescu, A., Mocanu, C. I., Păcuraru, F. D., Jagîte, G., "Estimation of planing forces in numerical and full scale experiment, International Maritime Association of the Mediteranean, Lisbon, 2017;

[26]. Tudose, V., Gheorghiu, H., Coterlici, R.F., Pastramă, S. D., Tudosege, D., "Studiu privind utilizarea unui compozit armat cu fibre de bumbac pentru obținerea căștilor de protecție”, Industria Textilă, Vol 67 nr. 2, p. 135-140, 2016;

Paper received on November $11^{\text {th }}, 2019$ 